\title{
Constructing a new cost structure using time-driven activity- based costing for replanting at palm oil plantation
}

\author{
S.N.A.M. Zaini ${ }^{* *}$ and M.Y. Abu ${ }^{1}$ \\ ${ }^{1}$ Faculty of Manufacturing and Mechatronic Engineering Technology, Universiti Malaysia Pahang, 26600, \\ Pekan, Pahang, Malaysia \\ *Email: areena5582@gmail.com
}

\begin{abstract}
The palm oil industry in Malaysia is undeniably the pride of the country. However, in this plantation there are currently few issues which do not set up a time equation to interpret the variance of activities, the rate setting did not illustrate the correlation between the resources provided and the practical capacity, and the manager had no tool in place to monitor the unused capacity. In order to increase precision in the field of palm oil plantation, this work aims to develop a new cost structure. Time-driven activity-based costing (TDABC) has been introduced because it allows time output to be efficiently assessed, the idle capacity accurately defined, and the unused capacity separately to be recorded. This provides an overview of functional tools and their associated costs as well as measurement methods and facilitates quality improvement. This work focused only on replanting field and the plantation located in Pahang. The maximum replanting capacity cost rate (CCR), with 288600 minutes and $0.106 \mathrm{RM} /$ minute, was subsequently successfully developed. Finally, the manager can observe that 68358.45 minutes of utilized capacity could be used for the systematic development of replanting capacity planning.
\end{abstract}

Indexed Terms- Palm oil plantation, time-driven activity-based costing, capacity cost rate, time equation, traditional cost accounting.

\section{INTRODUCTION}

Malaysia's palm oil industry showed an unfavourable performance compared to 2017 in 2018 . Fresh fruit yields, production of crude palm oil, and exports of palm oil decreased as palm oil importations grew, while palm oil stocks closed. This occurred because of a lack of model cost models became less prevalent, as the direct labor value of goods decreased. The application of the traditional method based on one foundation such as direct working hours contributes to a less precise and economic reality. The costing methodology proposed by Cooper and Kaplan assumes that many of the products use the same activities, which require resources in different quantities [1]. Costing based on activities is an approach proposed by Cooper and Kaplan. The estimate of cost of products and services is more accurate, in particular when it consists of a section of human activities and activities in a certain center [2]. They include mapping process and identifying value-adding activities, analyzing the costs of these activities and using cost drivers that were developed [3]. This methodology offers precise system modelling in order to evaluate the organization's business processes, and its implementation is very important when the largest share of expenses is assigned to the skilled workforce [4]. ABC is a suitable methodology for understanding the costs of highly complex systems, but the method is human-oriented. TDABC, however, is a changed $\mathrm{ABC}$ that assigns directly the cost of resources to value entities by means of a cost level on energy. This approach is based on its fundamental principle that value drivers are converted into time calculations which are time needed for carrying out an operation [5]. [6] had speculated the potential of cost reductions that would not jeopardize clinical performance through identifying causes of price variability on three locations. [7] reported that TDABC can enable managers concentrate on value-added activities and restrict value-added activities, which is very much required in any organization and that decision-making power in the adoption of policy deviations. [8], [9] and [10] 
applied TDABC in electric and electronic industry to reveal the important of time equation and capacity cost rate. [11] have agreed that TDABC can help decision makers to achieve the optimal product mix configuration. [12] have concluded that the TDABC streamlines the costing process by skipping potential interviews or employee surveys for the purposes of assigning resources cost. Thus, TDABC avoids the costly, time-consuming and subjective task of ABC monitoring activities. From 2010 to 2018, a survey was carried out on the application of TDABC consisting of 56 published journals as illustrated in Figure 1. There are three major industries that implement TDABC as their cost-computing system: health care, industrial and library. It has been demonstrated that no work is done with the TDABC system based on the previous investigation in the plantation.

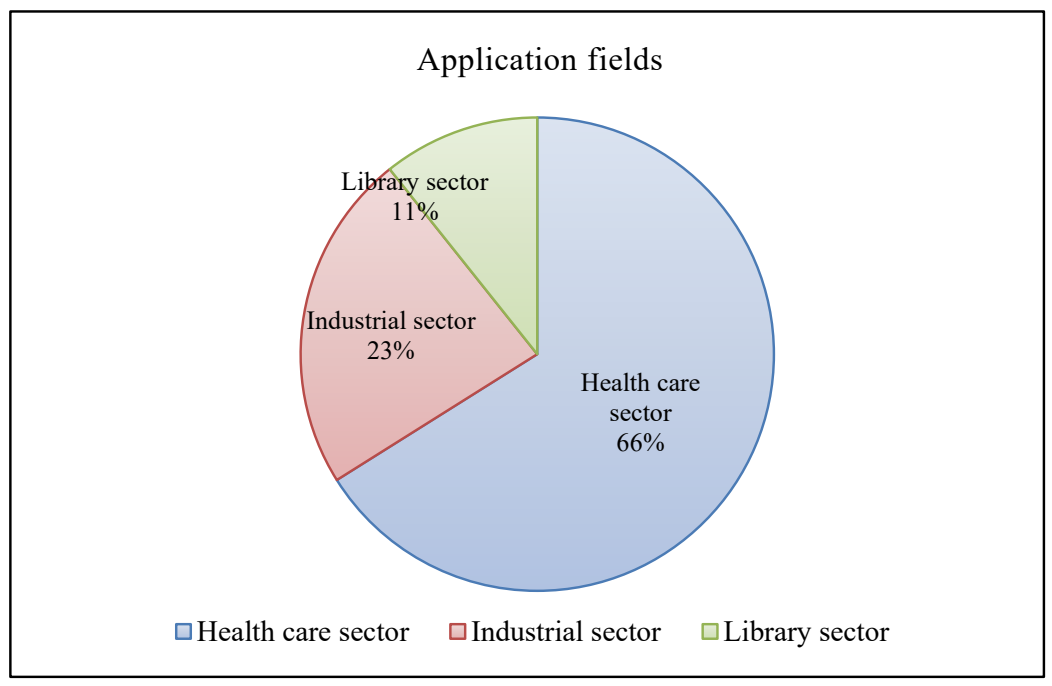

Figure 1: Application fields that using TDABC system

Considerable efforts have been made since 1997 to develop the ASEAN- 5 bond markets as an alternative financing channel for firms to obtain funds. Malaysia, Thailand and Singapore have larger bond markets relative to GDP compared to others, whereas BCLMV countries have just started to develop their bond markets. The stock markets and government bond markets in ASEAN-5 countries are very deep and liquid, but the corporate bond markets are shallow and illiquid. However, corporate bonds issuance started to grow rapidly since the 2008 global financial crisis driven mainly by the domestic market. The advantages of the TDABC have been divided into support for organizational improvement, notify reimbursement programs, correctly catch the care cost, manage the complexity underlying, more effective and simpler than conventional ABCs, which according to [13]. This study has therefore exploited the same elements to further summarize the research gap from previous works stated from 2010 to 2018 as shown in Figure 2.

The element that accurately capture the costs has the highest percentage according to Figure 2, with 39 percent as to the reason why TDABC can be applied. Subsequently, followed by $26 \%$ support operational improvement, the 21-percent for manage the complexity inherent, more efficient with $8 \%$ and finally simple than traditional $\mathrm{ABC}$ and inform reimbursement policy has the same $2 \%$. This work focused on the more productive aspect, as the established planting really needs a new and reliable costing system. [14] obtained all of the key elements of TDABC, including system modeling, resource cost ratios, time management and forecasts, by analyzing several crucial programs. The study is focused exclusively on industry. Apart from that, studies in industrial service were undertaken with only the application of two elements, capacities cost and time equations [15]. [16], [17] and [18] focused on process mapping, capacity cost rate and time equation in health care service. Also work by [19] applied the TDABC in library service, however, in a similar manner. 


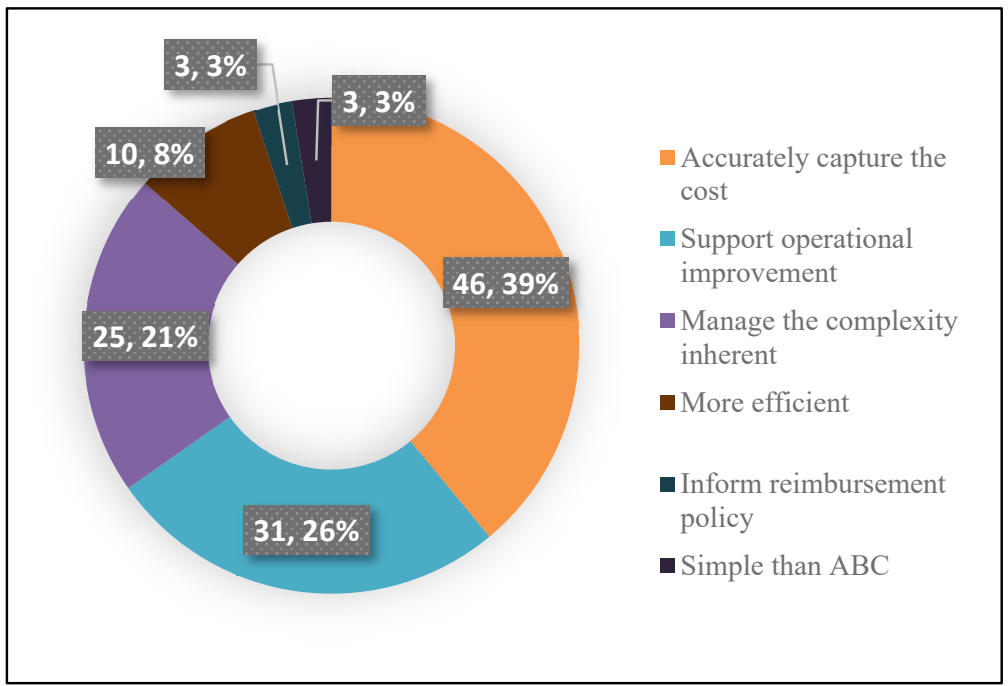

Figure 2: Distribution chart of reasons for applying TDABC

\section{METHODOLOGY}

The case study on the plantation in Muadzam Shah, Pahang was carried out. It has 3 major divisions and this project focuses on Division 1 of Simpai, which gathers all the information. Division 1 was then divided into three principal areas, mature, immature and replanting. In the mature area, all plants have been planted since 1990 and 1991, in 2015 as well as in 2016 for immature areas, and in 2017 the youngest plants have been replanted. Table 1 shows the specific plantation area of Simpai division with a total number of acres.

Table 1: Specific area of Simpai division 1

\begin{tabular}{|c|c|c|c|c|c|}
\hline & \multicolumn{2}{|c|}{ Mature } & \multicolumn{2}{|c|}{ Immature } & Re-planting /Immature \\
\hline & P90 A1 & P91 D1 & PR15 A1 & PR16 B1 & PR17 C1 \\
\hline & P90 A2 & P91 D2 & PR15 A2 & PR16 B2 & PR17 C2 \\
\hline & P90 A3 & P91 D3 & PR15 A3 & PR16 B3 & PR17 C3 \\
\hline & P90 A4 & P91 D4 & PR15 A4 & PR16 B4 & \\
\hline & P90 A5 & P91 D5 & & PR16 B5 & \\
\hline & P90 A6 & & & & \\
\hline & P90 A7 & & & & \\
\hline & P90 A8 & & & & \\
\hline Actual acre: & 894.2 & 651 & 531 & 560 & 449 \\
\hline TOTAL: & \multicolumn{2}{|c|}{1545.2} & \multicolumn{2}{|c|}{1091} & 3085.2 \\
\hline
\end{tabular}

Various activities and sub-activities take place from the ordered seeds to the harvesting and transportation of fresh fruit to the plant for the production of palm oil. There are three main centers of activity from which data and information have been collected. It begins with a nursery, then replanting fields and ends at ramp. Since this work deals with costing development, it is very important that data are collected for all activities. The new costing structure as shown in Figure 3 consists of four important elements from TDABC, which specifically involve 12 stages. The flow is divided into process mapping, development of the time equation, capacity cost rate and forecast analysis. 


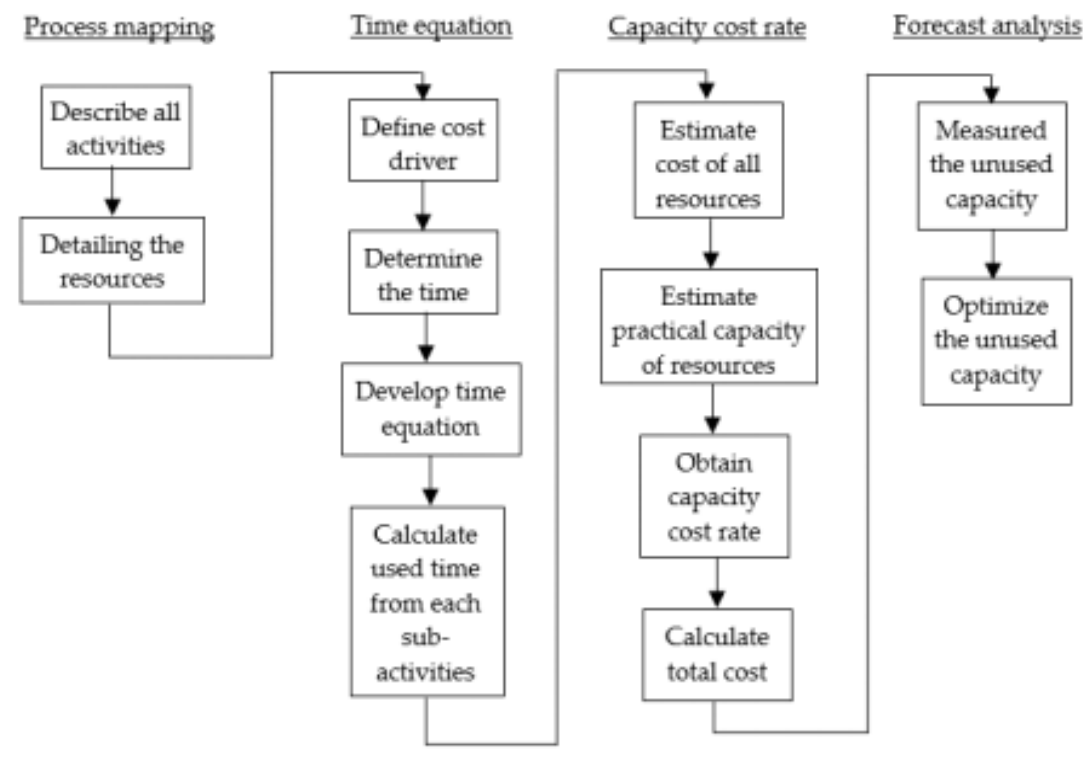

Figure 3: Flowchart of TDABC implementation

Various activities and sub-activities take place from the ordered seeds to the harvesting and transportation of fresh fruit to the plant for the production of palm oil. There are three main centers of activity from which data and information have been collected. It begins with a nursery, then replanting fields and ends at ramp. Since this work deals with costing development, it is very important that data are collected for all activities.

\section{RESULT AND DISCUSSION}

\subsection{Process mapping}

This dimension is very necessary if all the events that impact the final costs are to be established. The description of the operations indicates that actual costs and expenses are more precise. Figure 4 thus indicates an entire process in Simpai Division 1. This work divided the mapping into three main activity centres. The nursery activity center 1 comprises of two activities involving 5 sub-activities and 7 subactivities respectively. Center 2, activities for the field replanting process consists of eight activities that cover a lot of important sub-activities. The activity center 3 that focuses on the ramping phase is one operation with three sub-activities. This research showed that the division of the mapping into 3 centers effectively reduces waste in motion because centers 1 and 2 are quite far apart, thereby avoiding unnecessary operation while creating the time formula.

This initiative also focused on reconstruct the current expense structure in order to reduce the uncertainty for better understanding. The replanting operation starts with chipping, a phase in which old twisting palm trees help to keep the soil in planting areas healthy and clean. So, road and drain constructions create good access for quick and easy harvesting operations. In order for each pavement to have equal access to nutrients, water and sunlight, a maximum standing per hectare, regularly irrigated and processed palm tissues to be generated effectively and reliably, lining and holing must be calculated. Mucuna Brachteata planting is useful as a legume cover crop (LCC), as a fertilizer to soil supply, preserves the soil of the earth against degradation, increases the physical condition of the ground and helps control the weed. The large M. Bracteata may stop the beetle from consuming residual organic residues physically, despite the replanting of oil palm. On the other hand, the oil palm residues can be broken up more quickly in a humid environment. Therefore, M. Bracteata often inhibits rodent activity and thus decreases oil palm risk to rats. 


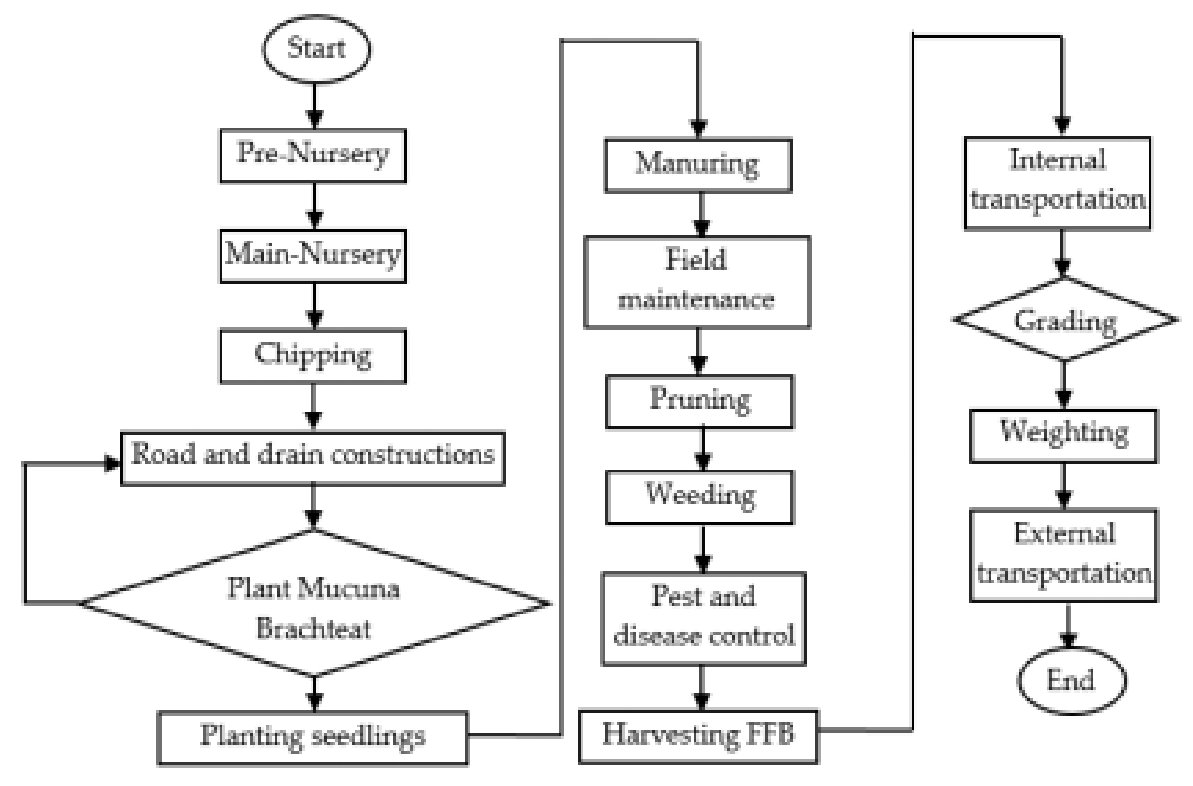

Figure 4: The work flow in Simpai division 1

When seedlings are transported and distributed, the supervisor shall record the number of seedlings taken from the nursery and the sum of the seedlings declined and plantings in the area. The farmers inspect the depth of the hole with the seed poly bag's height during planting seeds. First of all, split the poly bag's lower side, place the poly bag into the gap, split the poly bag head, cover the ground with the cover and dense the depth of the hole tightly to $1 / 3$, then cover up again to the poly bag neck end, and place plastic on the poly bag end of the stake, making each block's screen sheet. The controlled/slow release fertilizer (SRF) should be planted at the right times just below the surface of the soil and is the counterpart to seedlings for good growth. Pruning and weeding are very important to perform maintenance in the field by cutting off all dead leaves by using a spade. By introducing barn owls, it is possible to control biologically rat populations. To have a good owl population, install nest boxes every five to 10 hectares. Second, rodenticides are used as chemicals to kill rodents (rats) for rats baiting. Planting of beneficial plants such as Cassia cobanensis, Turnera subulata and Antigononon leptopus also assists in providing refuge and complementary food, such as nectar. In fact, Oryctes spraying (spraying the plant pest) to prevent an attack on a palm spear in the adult stages of Oryctes rhinos. The reference point is thus at the bottom of the layer of leaves. Last but not least, Pheromone trap system (Point of reproduction for Rhinoceros Beetle). The pheromone is contained in an interlocking metal vane in the thin, heat-dressed polymer membrane pocket. For oil palms to produce fruit suitable for harvest, it takes approximately four years. Instead, for up to 30 years, each tree continues to produce fruit, which is around 40 feet long. Palm fruits mature into thick bunches of 10 to 25 kilograms each with several thousand fruits each. Every year 12 to 14 of these bunches are produced by a healthy productive tree. The estate workers shall gather and place in wheelbarrow all bunches and loose fruits to avoid the germination of unqualified palm plant. Then the fresh fruit bunch (FFB) falls from the rickshaw to the fruit collection point (FCP) and loads the FFB manually into the tank. As the final transportation operation, oil palm tree bunches are transported within 24 hours of harvest to the collection center (ramp) and are closely managed to obtain maximum fruit value for palm oil extraction. By having this process mapping, this work identified a lot of resources required with respect to materials, expanses, maintenance and workers to be considered into the cost of capacity supplied. 


\subsection{Time equation}

The time formula is used for the incorporation of all sub-activities in a common calculation in every operation core. In order to develop it, it is crucial to consider the time for principal activities, time for additional sub-activities and its time driver. To measure the estimated time used, a time calculation is required. The estimated time for each activity was based on the principles of motion and time study. For instance, an average of approximately 15 minutes were found for transportation of harvested fruits from the collection point to the ramp. Table 2 defines each variable for replanting in the time equation.

Table 2: Time taken for the replanting

\begin{tabular}{|c|c|c|c|}
\hline No. & Sub-Activities & Minute & round \\
\hline \multicolumn{3}{|c|}{ Chipping } & \multirow[b]{3}{*}{4} \\
\hline 1. & Felling and shredding & 4 & \\
\hline & Total: & & \\
\hline \multicolumn{3}{|c|}{ Road and drain constructions } & \multirow[b]{5}{*}{485} \\
\hline 2. & Road and drain & 480 & \\
\hline 3. & Lining & 4 & \\
\hline 4. & Holing & 1 & \\
\hline & Total: & & \\
\hline \multicolumn{3}{|c|}{$\begin{array}{r} \\
\text { Planting }\end{array}$} & \\
\hline 5. & Legume cover crop (LCC) (Mucuna Brachteata) & 480 & \\
\hline 6. & Transportation and distribution of seedlings & 0.75 & \\
\hline 7. & Planting seedlings & 8 & \\
\hline & Total: & & 488.75 \\
\hline \multicolumn{3}{|c|}{ Manuring } & \\
\hline \multirow[t]{2}{*}{8.} & $\begin{array}{l}\text { Manuring programme based mainly on controlled/slow release } \\
\text { fertilizer (SRF) }\end{array}$ & 0.083 & \\
\hline & Total: & & 0.083 \\
\hline \multicolumn{3}{|c|}{ Field maintenance } & \\
\hline 9. & Pruning & 77922 & \\
\hline 10 . & Manual weeding & 38961 & \\
\hline \multirow[t]{2}{*}{11.} & Chemical weeding & 38961 & \\
\hline & Total: & & 155844 \\
\hline \multicolumn{3}{|c|}{ Pest and disease control } & \\
\hline 12. & Born out box & 620 & \\
\hline 13. & Rat baiting & 480 & \\
\hline 14. & Planting of beneficial plants & 60 & \\
\hline 15. & Oryctes spray (leaf pest spray) & 38961 & \\
\hline \multirow{2}{*}{16.} & Pheromone trap (oryctes breeding point) & 480 & \\
\hline & Total: & & 40601 \\
\hline \multicolumn{3}{|c|}{ Harvesting } & \\
\hline 17. & Harvesting fresh ftruit bunch (FFB) & 3 & \\
\hline 18. & Collect all bunches and loose fruits and placing them in wheelbarrow & 1 & \\
\hline 19. & FFB dropping from wheelbarrow to fruit collection point (FCP) & 1 & \\
\hline \multirow[t]{3}{*}{20.} & Manually loading FFB to truck bin (throwing up) & 1 & \\
\hline & Total: & & 6 \\
\hline & \multicolumn{2}{|l|}{ Internal transportation } & \\
\hline \multirow[t]{3}{*}{21.} & Transport FFB from field to ramp & 15 & \\
\hline & Total: & & 13 \\
\hline & TOTAL : & & 197441.83 \\
\hline
\end{tabular}

The total time taken for each round can be observed respectively for each replanting activity in Table 3. In every operation the total time taken is 240 minutes. The time driver depends on the 
characteristics of its activity that must be multiplied with the time activity or not. The time formula for each sub-activity must be calculated in this analysis, the capacity used (minute / month). Through quantifying the intensity of the activities in one month, the average capability needed by each operation was calculated. When the amount of an activity is multiplied by the time it was spent, the total time spent on the activity could be calculated. The volumes of cost-drivers for the activity centers are summarized in Table 3.

Table 3: Volume of cost-drivers for replanting field

\begin{tabular}{|c|c|c|}
\hline Var. & Driver & $\begin{array}{l}\text { Quantity/ } \\
\text { month }\end{array}$ \\
\hline \multicolumn{3}{|c|}{$\begin{array}{r}\text { Chipping } \\
\end{array}$} \\
\hline $\mathrm{X}_{1}$ & Felling and shredding (amount of palms) & 12025 \\
\hline \multicolumn{3}{|c|}{ Road and drain constructions } \\
\hline $\mathrm{X}_{2}$ & Road and drain (rounds) & 200 \\
\hline $\mathrm{X}_{3}$ & Lining (amount of palms) & 12025 \\
\hline $\mathrm{X}_{4}$ & Holing (rounds) & 32.46 \\
\hline \multicolumn{3}{|c|}{ Planting } \\
\hline $\mathrm{X}_{5}$ & Legume cover crop (LCC) (Mucuna Brachteata) (rounds) & 16.23 \\
\hline $\mathrm{X}_{6}$ & Transportation and distribution of seedlings (rounds) & 24050 \\
\hline $\mathrm{X}_{7}$ & Planting seedlings (amount of palms) & 24050 \\
\hline \multicolumn{3}{|c|}{ Manuring } \\
\hline $\mathrm{X}_{8}$ & Manuring programme (amount of palms) & 24050 \\
\hline \multicolumn{3}{|c|}{$\begin{array}{l}\text { Field maintenance } \\
\end{array}$} \\
\hline $\mathrm{X}_{9}$ & Pruning (rounds) & 0.167 \\
\hline $\mathrm{X}_{10}$ & Manual weeding (rounds) & 0.5 \\
\hline $\mathrm{X}_{11}$ & Chemical weeding (rounds) & 1 \\
\hline \multicolumn{3}{|c|}{ Pest and disease control } \\
\hline $\mathrm{X}_{12}$ & Born out box (rounds) & 0.083 \\
\hline $\mathrm{X}_{13}$ & Rat baiting (rounds) & 2 \\
\hline $\mathrm{X}_{14}$ & Planting of beneficial plants (rounds) & 0.083 \\
\hline $\mathrm{X}_{15}$ & Oryctes spray (leaf pest spray) (rounds) & 0.083 \\
\hline $\mathrm{X}_{16}$ & Pheromone trap (oryctes breeding point) (rounds) & 1 \\
\hline \multicolumn{3}{|c|}{ Harvesting } \\
\hline $\mathrm{X}_{17}$ & Harvesting fresh fruit bunch (FFB) (amount of palms) & 48100 \\
\hline $\mathrm{X}_{18}$ & Collect all bunches and loose fruits into wheelbarrow (amount of palms) & 48100 \\
\hline $\mathrm{X}_{19}$ & FFB dropping from wheelbarrow to fruit collection point (amount of palms) & 48100 \\
\hline $\mathrm{X}_{20}$ & Manually loading FFB to truck bin (throwing up) (amount of palms) & 48100 \\
\hline \multicolumn{3}{|c|}{ Internal transportation } \\
\hline $\mathrm{X}_{21}$ & Transport FFB from field to ramp & 100.21 \\
\hline
\end{tabular}

The quantity of palms to be planted and shredded during replanting for chipping is 12025 per month, covering half of the entire total area of 400,83 acres. In this process, a worker may drop by using an extractor and cut 120 old palms ( 2 acres) per month. The accommodation period granted for the clearance of land is 2 months before the planters could start planting, accompanied by other subactivities for another 3 months. There are 200 rounds / month for road and drain constructions. This is due to the fact that this process must be resolved within two months of the plantation. The chipping process in the furnace is the same. Therefore, in holing, 34.95 rounds are needed in one month for the entire area. A worker will finish an average of 5 hectares per day for every round (12.35 hectares or 741 holes). This requires just 16.23 rounds a month to plant the beneficial plant (Mucuna Brachteata), which has been performed only once a year. Both seedlings are distributed and planted with 24050 rounds, the same cost driver. The process of manuring the palms planted according to the number of palms planted. In terms of field maintenance, pruning only took 0.167 rounds a month, as pruning is needed once in a 
year. Weeding is performed manually for 0.5 round per month for every two months. Nevertheless, comparison to manual weeding, chemical weeding has a double the rate. The chemical is regularly sprayed once every month. In fact, the prevention for insect or disease is done to prevent any crop defects. Born from box, planting of advantageous crops and Oryctes spray has the same number of rounds that is 0.083 . All three events occur only once a year. In addition, pheromone trap is regularly set up every month. Twice a month only rat baiting is provided to avoid the rat current. A harvester capable of harvesting around 2.5 acres, equivalent to 150 palms. For one month, the cumulative palm trees for two phases are equivalent to 400,83 acres, of which 4,8100 palm trees are grown. For two cycles in one month each mature palm has to be harvested. The large number of rounds of palms required for all sub-activities in the harvest fields per month. A tractor journey can take 8 tons of FFB. In one month, it took 100.21 rounds from field to ramp to move a maximum of 801,66 tons of FFB. Three trips are necessary for an employee. Time equation is able to incorporate all the time needed to undertake all sub-activities in each activity centre as shown in equation (1).

$\mathrm{T}_{\mathrm{t}}=\beta_{0}+\beta_{\mathrm{i}} \mathrm{X}_{\mathrm{i}}$

Where:

$\mathrm{T}_{\mathrm{t}}=$ the time needed to perform an activity (minute).

$\beta_{\mathrm{o}}=$ the standard time to perform the basic activity (minute).

$\beta_{i}=$ the estimated time to perform the incremental activity (minute).

$\mathrm{X}_{\mathrm{i}}=$ the quantity of the incremental activity (time).

Table 2 was then multiplied by the relevant variables in Table 3 or cost-drivers to develop a complete time equation for ramp as shown in Table 4.

Table 4: Time equations for sub-activities of the replanting

\begin{tabular}{cll}
\hline No. & Activities & Time Equations \\
\hline 1. & Chipping & $4 \mathrm{X}_{1}$ \\
2. & Road and drain constructions & $480 \mathrm{X}_{2}+4 \mathrm{X}_{3}+741 \mathrm{X}_{4}$ \\
3. & Planting & $480 \mathrm{X}_{5}+0.75 \mathrm{X}_{6}+8 \mathrm{X}_{7}$ \\
4. & Manuring & $0.083 \mathrm{X}_{8}$ \\
5. & Field maintenance & $77922 \mathrm{X}_{9}+38961 \mathrm{X}_{10}+38961 \mathrm{X}_{11}$ \\
6. & Pest and disease control & $620 \mathrm{X}_{12}+480 \mathrm{X}_{13}+60 \mathrm{X}_{14}+38961 \mathrm{X}_{15}+480 \mathrm{X}_{16}$ \\
7. & Harvesting & $3 \mathrm{X}_{17}+\mathrm{X}_{18}+\mathrm{X}_{19}+\mathrm{X}_{20}$ \\
8. & Internal transportation (field to ramp) & $15 \mathrm{X}_{21}$ \\
\hline
\end{tabular}

From Table 4, the time equation for the activity center 3 was developed as shown in equation (2).

$\mathrm{T}_{\text {replanting }}=4 \mathrm{X}_{1}+480 \mathrm{X}_{2}+4 \mathrm{X}_{3}+741 \mathrm{X}_{4}+480 \mathrm{X}_{5}+0.75 \mathrm{X}_{6}+8 \mathrm{X}_{7}+0.083 \mathrm{X}_{8}+77922 \mathrm{X}_{9}+38961 \mathrm{X}_{10}+$ $38961 X_{11}+620 X_{12}+480 X_{13}+60 X_{14}+38961 X_{15}+480 X_{16}+3 X_{17}+X_{18}+X_{19}+X_{20}+15 X_{21}$

After the time equations for the activity centers were created, the time equation to calculate the total time spent in a cycle of palm oil's growth is presented in equation (3) as shown below.

$\mathrm{T}_{\text {total }}=\mathrm{T}_{\text {nursery }}+\mathrm{T}_{\text {replanting }}+\mathrm{T}_{\text {ramp }}$

Table 5 shows on how to get the actual used capacity for each sub-activities in all activity centers by multiplying the value of quantity or round needed for each sub-activities per month with total time taken for every round. 
Table 5: Total used time for sub-activities of the replanting

\begin{tabular}{|c|c|c|c|c|}
\hline Var & Driver & $\begin{array}{l}\text { Quantity/ } \\
\text { month }\end{array}$ & Minute/round & $\begin{array}{r}\text { Used capacity } \\
(\mathrm{min} / \mathrm{month}) \\
\end{array}$ \\
\hline \multicolumn{5}{|c|}{ Chipping } \\
\hline $\mathrm{X}_{1}$ & Felling and shredding (amount of palms) & 12025 & 4 & 48100 \\
\hline & Total: & & & 48100 \\
\hline \multicolumn{5}{|c|}{ Road and drain constructions } \\
\hline $\mathrm{X}_{2}$ & Road and drain (rounds) & 200 & 480 & 96000 \\
\hline $\mathrm{X}_{3}$ & Lining (amount of palms) & 12025 & 4 & 48100 \\
\hline $\mathrm{X}_{4}$ & Holing (rounds) & 32.46 & 741 & 24052.86 \\
\hline & Total: & & & 216252.86 \\
\hline \multicolumn{5}{|c|}{ Planting } \\
\hline $\mathrm{X}_{5}$ & $\begin{array}{l}\text { Legume cover crop (LCC) (Mucuna } \\
\text { Brachteata) (rounds) }\end{array}$ & 16.23 & 480 & 7790.4 \\
\hline $\mathrm{X}_{6}$ & $\begin{array}{l}\text { Transportation and distribution of } \\
\text { seedlings (rounds) }\end{array}$ & 24050 & 0.75 & 18037.5 \\
\hline $\mathrm{X}_{7}$ & Planting seedlings (amount of palms) & 24050 & 8 & 192400 \\
\hline & Total: & & & 218227.9 \\
\hline \multicolumn{5}{|c|}{ Manuring } \\
\hline $\mathrm{X}_{8}$ & $\begin{array}{l}\text { Manuring programme based mainly on } \\
\text { controlled/slow release fertilizer } \\
\text { (SRF)(amount of palms) }\end{array}$ & 24050 & 0.083 & 1996.15 \\
\hline & Total: & & & 1996.15 \\
\hline \multicolumn{5}{|c|}{ Field maintenance } \\
\hline $\mathrm{X}_{9}$ & Pruning (rounds) & 0.167 & 77922 & 13012.97 \\
\hline $\mathrm{X}_{10}$ & Manual weed (rounds) & 0.5 & 38961 & 19480.5 \\
\hline $\mathrm{X}_{11}$ & Chemical weed (rounds) & 1 & 38961 & 38961 \\
\hline & Total: & & & 71454.47 \\
\hline \multicolumn{5}{|c|}{ Pest and disease control } \\
\hline $\mathrm{X}_{12}$ & Born out box (rounds) & 0.083 & 620 & 51.46 \\
\hline $\mathrm{X}_{13}$ & Rat baiting (rounds) & 2 & 480 & 960 \\
\hline $\mathrm{X}_{14}$ & Planting of beneficial plants (rounds) & 0.083 & 60 & 4.98 \\
\hline $\mathrm{X}_{15}$ & Oryctes spray (leaf pest spray) (rouds) & 0.083 & 38961 & 3233.76 \\
\hline $\mathrm{X}_{16}$ & $\begin{array}{l}\text { Pheromone trap (oryctes } \\
\text { breeding/point) (rounds) }\end{array}$ & 1 & 480 & 480 \\
\hline & Total: & & & 4730.2 \\
\hline \multicolumn{5}{|c|}{ Harvesting } \\
\hline $\mathrm{X}_{17}$ & $\begin{array}{l}\text { Harvesting fresh fruit bunch (FFB) } \\
\text { (amount of palms) }\end{array}$ & 48100 & 3 & 144300 \\
\hline $\mathrm{X}_{18}$ & $\begin{array}{l}\text { Collect all bunches and loose fruits and } \\
\text { placing them in wheelbarrow (amount of } \\
\text { palms) }\end{array}$ & 48100 & 1 & 48100 \\
\hline $\mathrm{X}_{19}$ & $\begin{array}{l}\text { FFB dropping from wheelbarrow to fruit } \\
\text { collection point (FCP) (amount of palms) }\end{array}$ & 48100 & 1 & 48100 \\
\hline \multirow[t]{3}{*}{$X_{20}$} & $\begin{array}{l}\text { Manually loading FFB to truck bin } \\
\text { (throwing up) (amount of palms) }\end{array}$ & 48100 & 1 & 48100 \\
\hline & Total: & & & 288600 \\
\hline & Internal transportation & & & \\
\hline \multirow[t]{3}{*}{$\mathrm{X}_{21}$} & $\begin{array}{l}\text { Transportation of FFB from field to ramp } \\
\text { (rounds) }\end{array}$ & 100.21 & 15 & 1503.15 \\
\hline & Total: & & & 1503.15 \\
\hline & TOTAL: & & & 861881.55 \\
\hline
\end{tabular}


According to Table 5, the total used capacity for replanting is 861881.55 . The actual time spent (used capacity) on this activity center per month was determined by substituting the volume of costdrivers from Table 3 with equation (2) as follow.

The actual time spent (used capacity) in activity center 2 , replanting filed $=(4 \times 12025)+(480 \times 200)+$ $(4 \times 12025)+(741 \times 32.46)+(480 \times 16.23)+(0.75 \times 24050)+(8 \times 24050)+(0.083 \times 24050)+$ $(77922 \times 0.167)+(38961 \times 0.5)+(38961 \times 1)+(620 \times 0.083)+(480 \times 2)+(60 \times 0.083)+(38961 \times 0.083)+$ $(480 \times 1)+(3 \times 48100)+(1 \times 48100)+(1 \times 48100)+(1 \times 48100)+(15 \times 100.21)=861881.55$ minutes.

If the resources used fall under the same activity, the cost of this activity may be allocated directly. However, an allocation method based on the appropriate cost driver should be employed if resources are used for several activities. Participants in this analysis are split into two groups: (i) the costs of operation and (ii) the expense of the equipment, machinery and other resources depending on the categories of tool used for each task. All plant workers are paid a basic wage of RM 1300 except for nursery employees, ramp, harvesters and FFB transport workers. Estimated costs of all the resources used in each of the sub-activities described above are summarized in Table 6.

The chipping phase includes four staff each month at a cost of RM1300, which totals RM5200. The overhead cost for chipping is the rental of machinery that works on 200.42 acres of land at RM1924.89 for a month. RM24660.57 has been spent on the cost of roads and drains involving 14 employees, rental of machines and culvert / footbridges. This also applies to half of the total hectare. The cost in planting area for labor is RM19500 and overhead is RM32456. Cost of manuring is classified as RM850/ha or RM344.13/acre. Six staff are used to help field operations but only four of them are charged a surcharge, RM0.01 per palm on which they have served. The four work to spray chemical spinning. Therefore, RM24347,60 cost for this point. The total cost of all services provided in this process is RM8181.03 for the care of pests and diseases. Harvester used machines worth RM600 made from carbon fiber content for harvesting FFB. As in this sub-activity only ten workers are allocated, the overhead expense is RM6000. RM24049.8 is used for 21 employees in this process. Total RM30049.80 is required. The overhead price per ton for every journey is in internal transport (field to ramp) which is RM26. In one month, 801.66 tons of FFB are normally collected. Overhead costs therefore amount to RM20843.16. Practical capacities suggest current activities with respect to the resources available to accomplish the actual sector. The work hours of the plantation are from 8 am to $6 \mathrm{pm}$ from Monday to Saturday and from 8 am until $1 \mathrm{pm}$ on Sunday. The workforce works on average 8 hours per day between Mondays and Saturdays (26 days per month) and 5 hours on Sundays ( 4 days per month). There are no deductions from these work hours for breaks, training and maintenance, so employees have an acceptable capacity of 13,680 minutes per month. Table 7 shows the summary of capacity cost rate (CCR) for each activity for replanting.

In this case, manuring activity have the maximum capacity cost (CCR) value which is 5.137 . The minimum CCR value, by contrast, is 0.106 from the harvesting activity. The idle potential can be measured directly by using this value as guide. 
Table 6: Labor, equipment, machinery and other equipment costs within the replanting

\begin{tabular}{|c|c|c|c|c|}
\hline No & Sub-Activities & Labor costs & Overheads & $\begin{array}{c}\text { Cost of all } \\
\text { resources } \\
\text { supplied }\end{array}$ \\
\hline \multicolumn{5}{|c|}{ Chipping } \\
\hline \multirow[t]{2}{*}{1.} & Felling and shredding & 5200 & 1924.89 & 7124.89 \\
\hline & Total: & 5200 & 1924.89 & 7124.89 \\
\hline \multicolumn{5}{|c|}{ Road and drain constructions } \\
\hline 2. & Road and drain construction & 5200 & 7135.68 & 12335.68 \\
\hline 3. & Lining & 7800 & - & 7800 \\
\hline \multirow[t]{2}{*}{4.} & Holing & 2600 & 1924.89 & 4524.89 \\
\hline & Total: & 15600 & 9060.57 & 24660.57 \\
\hline & Planting & & & \\
\hline 5 . & $\begin{array}{l}\text { Legume cover crop (LCC) (Mucuna } \\
\text { brachteata) }\end{array}$ & 1300 & 32456 & 33756 \\
\hline 6. & Transportation and distribution of seedlings & 9100 & - & 9100 \\
\hline \multirow[t]{2}{*}{7.} & Planting seedlings & 9100 & - & 9100 \\
\hline & Total: & 19500 & 32456 & 51956 \\
\hline \multicolumn{5}{|c|}{ Manuring } \\
\hline \multirow[t]{2}{*}{8.} & $\begin{array}{l}\text { Manuring programme based mainly on } \\
\text { controlled/slow release fertilizer (SRF) }\end{array}$ & 2600 & 137938 & 140538 \\
\hline & Total: & 2600 & 137938 & 140538 \\
\hline \multicolumn{5}{|c|}{ Field maintenance } \\
\hline 9. & Pruning & 2600 & 835.06 & 3435.06 \\
\hline 10. & Manual weeding & 2840.5 & 4809.96 & 7650.46 \\
\hline \multirow[t]{2}{*}{11.} & Chemical weeding & 2840.5 & 10421.58 & 13262.08 \\
\hline & Total: & 8281 & 16066.6 & 24347.6 \\
\hline \multicolumn{5}{|c|}{ Pest and disease control } \\
\hline 12. & Born out box & 325 & 31.25 & 356.25 \\
\hline 13. & Rat baiting & 325 & 1362.82 & 1689.82 \\
\hline 14. & Planting of beneficial plants & 325 & 37.41 & 362.41 \\
\hline 15. & Oryctes spray (leaf pest spray) & 2840.5 & 167.01 & 3007.51 \\
\hline \multirow[t]{2}{*}{16.} & Pheromone trap (oryctes breeding point) & 325 & 2433.04 & 2758.04 \\
\hline & Total: & 4140.5 & 4031.53 & 8181.03 \\
\hline \multicolumn{5}{|c|}{ Harvesting } \\
\hline 17. & Harvesting fresh fruit bunch (FFB) & 12024.9 & 6000 & 18024.9 \\
\hline 18. & $\begin{array}{l}\text { Collect all bunches and loose fruits and } \\
\text { placing them in wheelbarrow }\end{array}$ & 4008.3 & - & 4008.3 \\
\hline 19. & $\begin{array}{l}\text { FFB dropping from wheelbarrow to fruit } \\
\text { collection point (FCP) }\end{array}$ & 4008.3 & - & 4008.3 \\
\hline \multirow[t]{2}{*}{20.} & $\begin{array}{l}\text { Manually loading FFB to truck bin } \\
\text { (Throwing Up) }\end{array}$ & 4008.3 & - & 4008.3 \\
\hline & Total: & 24049.8 & 6000 & 30049.8 \\
\hline & Internal transportation & & & \\
\hline \multirow[t]{3}{*}{21.} & Transport FFB from field to ramp & 2404.98 & 20843.16 & 23248.14 \\
\hline & Total: & 2404.98 & 20843.16 & 23248.14 \\
\hline & TOTAL: & 81776.28 & 228320.75 & 310106.03 \\
\hline
\end{tabular}


Table 7: CCR of each sub-activity for the replanting

\begin{tabular}{|c|c|c|c|c|}
\hline No & Sub-Activities & $\begin{array}{l}\text { Cost of all } \\
\text { resources } \\
\text { supplied } \\
\text { (RM/month) }\end{array}$ & $\begin{array}{c}\text { Practical } \\
\text { capacity } \\
\text { (min/month) }\end{array}$ & $\begin{array}{c}\text { Capacity } \\
\text { cost rate } \\
(\mathrm{RM} / \mathrm{min})\end{array}$ \\
\hline \multicolumn{5}{|c|}{ Chipping } \\
\hline \multirow[t]{2}{*}{1.} & Felling and shredding & 7124.89 & 54720 & \\
\hline & Total: & 7124.89 & 54720 & 0.13 \\
\hline \multicolumn{5}{|c|}{ Road and drain constructions } \\
\hline 2. & Road and drain construction & 12335.68 & 54720 & \\
\hline 3. & Lining & 7800 & 82080 & \\
\hline 4. & Holing & 4524.89 & 27360 & \\
\hline & Total: & 24660.57 & 218880 & 0.113 \\
\hline \multicolumn{5}{|c|}{ Planting } \\
\hline 5. & $\begin{array}{l}\text { Legume cover crop (LCC) (Mucuna } \\
\text { brachteata) }\end{array}$ & 33756 & 13680 & \\
\hline 6. & Trasnportation and distribution of seedlings & 9100 & 95760 & \\
\hline 7. & Planting seedlings & 9100 & 95760 & \\
\hline & Total: & 51956 & 191520 & 0.271 \\
\hline \multicolumn{5}{|c|}{ Manuring } \\
\hline \multirow[t]{2}{*}{8.} & $\begin{array}{l}\text { Manuring programme based mainly on } \\
\text { controlled/slow release fertilizer (SRF) }\end{array}$ & 140538 & 27360 & \\
\hline & Total: & 140538 & 27360 & 5.137 \\
\hline \multicolumn{5}{|c|}{ Field maintenance } \\
\hline 9. & Pruning & 3435.06 & 27360 & \\
\hline 10. & Manual weeding & 7650.46 & 27360 & \\
\hline \multirow[t]{2}{*}{11.} & Chemical weeding & 13262.08 & 27360 & \\
\hline & Total: & 24347.6 & 109440 & 0.222 \\
\hline \multicolumn{5}{|c|}{ Pest and disease control } \\
\hline 12. & Born out box & 356.25 & 3420 & \\
\hline 13. & Rat baiting & 1689.82 & 3420 & \\
\hline 14. & Planting of beneficial plants & 362.41 & 3420 & \\
\hline 15. & Oryctes spray (leaf pest spray) & 3007.51 & 27360 & \\
\hline \multirow[t]{3}{*}{16.} & Pheromone trap (oryctes breeding point) & 2758.04 & 3420 & \\
\hline & Total: & 8181.03 & 41040 & 0.200 \\
\hline & Harvesting & & & \\
\hline 17. & Harvesting fresh ftruit bunch (FFB) & 18024.9 & 136800 & \\
\hline 18. & $\begin{array}{l}\text { Collect all bunches and loose fruits and } \\
\text { placing them in wheelbarrow }\end{array}$ & 4008.3 & 45600 & \\
\hline 19. & $\begin{array}{l}\text { FFB dropping from wheelbarrow to fruit } \\
\text { collection point (FCP) }\end{array}$ & 4008.3 & 45600 & \\
\hline \multirow[t]{3}{*}{20.} & $\begin{array}{l}\text { Manually loading FFB to truck bin } \\
\text { (Throwing Up) }\end{array}$ & 4008.3 & 56544 & \\
\hline & Total: & 30049.8 & 284544 & 0.106 \\
\hline & Internal transportation & & & \\
\hline \multirow[t]{3}{*}{21.} & Transport FFB from field to ramp & 23248.14 & 2736 & \\
\hline & Total: & 23248.14 & 2736 & 8.497 \\
\hline & TOTAL: & 310106.03 & 930240 & \\
\hline
\end{tabular}




\subsection{Forecast analysis}

The resources planning system is split into three phases, which define service standards, assess current capabilities and possible predictions. Three phases exist in this first step: workloads, the unit of work and the levels of service are determined. The current production plan is then reviewed to determine how each task or process can be assessed in its entirety. In the final stage, the forecasting strategy is drawn up to know the expected amount of incoming jobs in the coming lots. Through the study of capacity utilization, the author has therefore suggested methods of cutting costs, with a view to increasing production efficiency and growing waste costs. An example on how this might be done for palm oil plantation activity centers of replanting are described in Table 8.

Table 8: Analysis of capacity utilization in the palm oil plantation activity centre

\begin{tabular}{|c|c|c|c|c|c|c|}
\hline Activities & $\begin{array}{c}\text { Practical } \\
\text { capacity } \\
\text { (min/month) }\end{array}$ & $\begin{array}{c}\text { Used } \\
\text { capacity } \\
(\mathrm{min})\end{array}$ & $\begin{array}{c}\text { Unused } \\
\text { capacity } \\
(\mathrm{min})\end{array}$ & $\begin{array}{l}\text { Capacity } \\
\text { cost rate } \\
(\mathrm{RM} / \mathrm{min})\end{array}$ & $\begin{array}{c}\text { Waste } \\
\text { cost } \\
(\mathrm{RM})\end{array}$ & $\begin{array}{c}\text { Utilization } \\
\text { cost } \\
(\mathrm{RM}) \\
\end{array}$ \\
\hline \multicolumn{7}{|l|}{ Replanting } \\
\hline Chipping & 54720 & 48100 & 6620 & 0.130 & 860.6 & 6253 \\
\hline $\begin{array}{l}\text { Road and drain } \\
\text { constructions }\end{array}$ & 218880 & 216252.86 & 2627.14 & 0.113 & 296.87 & 24436.57 \\
\hline Planting seedlings & 191520 & 218227.9 & -26707.9 & 0.271 & -7237.84 & 59139.76 \\
\hline Manuring & 27360 & 1996.15 & 25363.85 & 5.137 & 130294.1 & 10254.22 \\
\hline Field maintenance & 109440 & 71454.47 & 37985.53 & 0.222 & 8432.79 & 15862.89 \\
\hline $\begin{array}{l}\text { Pest and disease } \\
\text { control }\end{array}$ & 41040 & 4730.2 & 36309.8 & 0.200 & 7261.96 & 946.04 \\
\hline Harvesting & 284544 & 288600 & -4056 & 0.106 & -429.94 & 30591.6 \\
\hline $\begin{array}{l}\text { Internal Transportation } \\
\text { (field to ramp) }\end{array}$ & 2736 & 1503.15 & 1232.85 & 8.497 & 145.09 & 12772.27 \\
\hline Total: & 930240 & 861881.55 & 68358.45 & & 139623.63 & 160256.35 \\
\hline
\end{tabular}

After analysis of the planting cost using TDABC, as summarized in Table 8, the researchers were able to determine unused capacities which lead to waste costs. This reveals that the waste price is the largest at RM139623.63 in the replanting operation core. It was discovered that the greatest loss was caused by manuring sub-activity. The workers should be employed in another activity with insufficient work capacity, for example in the planting of seedlings, as that will help lower the unused capacity.

The resources used would impact the costs of use and the idle capacity would contribute to excess expense current. Each business center has different CCRs so the use rate and waste costs are different. In this graph, it shows that the replanting center has the highest rate for every analysis because it contains the majority of processes. The activity center reveals only small differences in the grades of diagrams for use and loss price. In general, however, usage costs are higher than those of RM139623.6, which is RM160256.35. The manager should find solutions that minimize waste costs, such as cutting the number of employees, reducing working hours or spending time on other complicated businesses requiring extra workforce. The seedling cycle is an illustration of a sub-activity that many people need to solve their job scarcity. The practical capacity provided is 218227.9 minutes each month, but it takes an additional 26707.9 minutes to reach the target. This work found that TDABC could identify total costs in accordance with the actual use of planting industry resources. The costs of each activity were found to be different because of the different factors affecting resources and capacity costs. Complex activity requires longer time and those involving many processes tend to be further increased. The results of this study provided the case study firm with a clear picture of what could be improved to reduce waste costs and improve working power. The study also demonstrated the additional value and unnecessary practices and the challenges in the planting process. Resource waste can be reduced by improving efficiency, in particular by optimizing resources for practical capacity. 


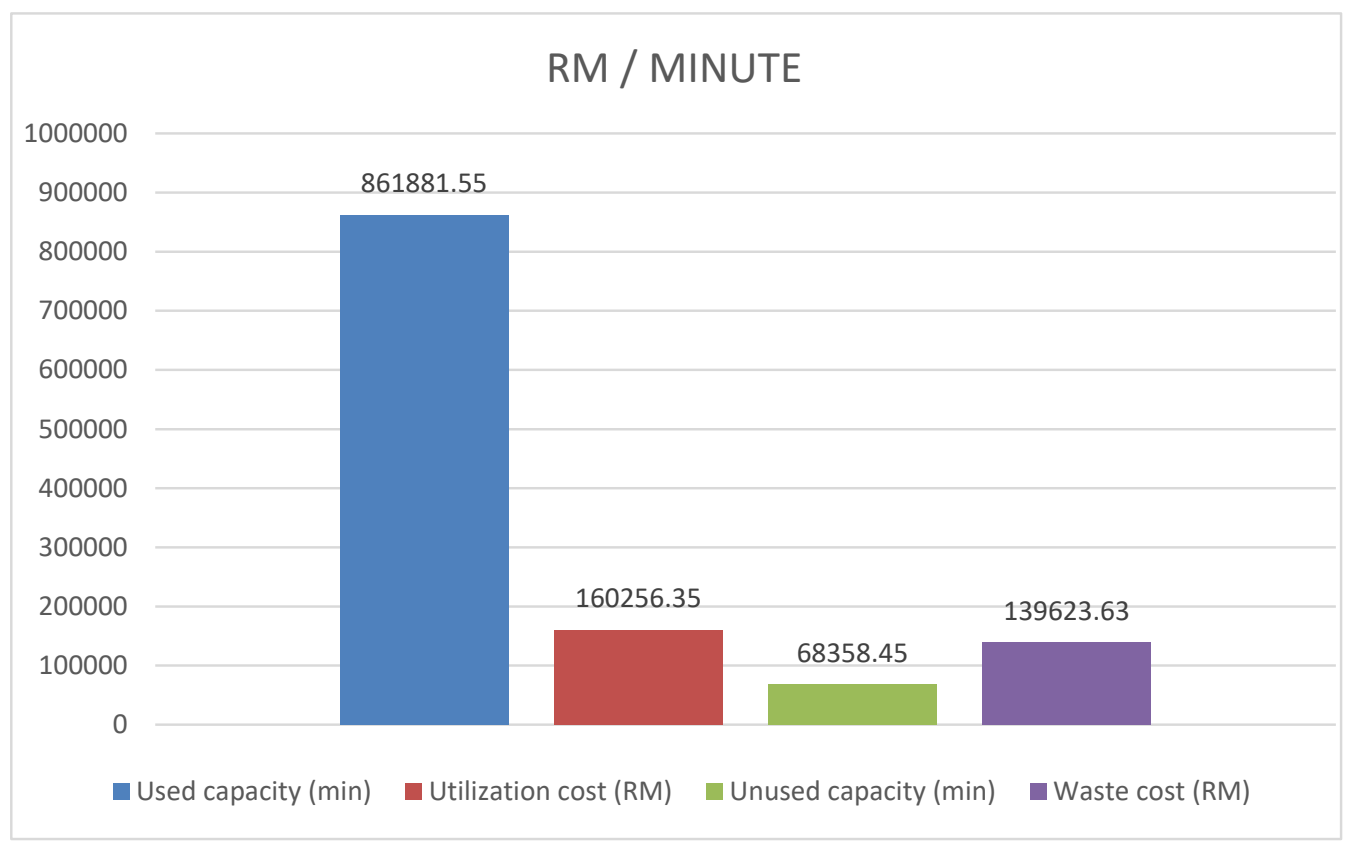

Figure 5: Graph of used capacity with utilization costs and unused capacity with waste costs

\section{CONCLUSION}

The method mapping for the replanting area of the palm oil plantation was a good innovation for this research. It is shown that all activity centers are directly proportional to the price of their facilities. Thus, the time equation constructed as $\mathrm{T}_{\text {replanting }}=4 \mathrm{X}_{1}+480 \mathrm{X}_{2}+4 \mathrm{X}_{3}+741 \mathrm{X}_{4}+480 \mathrm{X}_{5}+0.75 \mathrm{X}_{6}+8 \mathrm{X}_{7}+$ $0.083 \mathrm{X}_{8}+77922 \mathrm{X}_{9}+38961 \mathrm{X}_{10}+38961 \mathrm{X}_{11}+620 \mathrm{X}_{12}+480 \mathrm{X}_{13}+60 \mathrm{X}_{14}+38961 \mathrm{X}_{15}+480 \mathrm{X}_{16}+3 \mathrm{X} 1_{7}$ $+\mathrm{X}_{18}+\mathrm{X}_{19}+\mathrm{X}_{20}+15 \mathrm{X}_{21}$ and from this equation, the total used capacity was 861881.55 minutes. Time equation and CCR can act as a tool for the manager to assess the unused capacity. From the value of unused capacity of 68358.45 minutes means the manager can reduce the resources for better saving. Therefore, the manager has a clear view to reduce production costs based on the analysis of capacity utilization in order to increase working capacity and decrease waste costs.

\section{ACKNOWLEDGEMENT}

The authors would like to thank to the Universiti Malaysia Pahang and Ministry of Education Malaysia for financial assistance under Research Grant project No. RDU190156 and FRGS/1/2018/TK03/UMP/02/34.

\section{REFERENCES}

[1] Cooper R. and Kaplan R.S. "Profit priorities from activity-based costing", Harv Bus Rev, 69(3), 130-135, 1991.

[2] Abu M.Y., Jamaludin K.R. and Zakaria M.A. "Characterisation of activity based costing on remanufacturing crankshaft", International Journal of Automotive and Mechanical Engineering, 14(2), 4211-4224, 2017.

[3] Kamil N.N.N.M. and Abu M.Y. "Integration of mahalanobis-taguchi system and activity based costing for remanufacturing decision", Journal of Modern Manufacturing Systems and Technology, 1,39-51, 2018. 
[4] Abu M.Y., Nor E.E.M. and Rahman M.S.A. "Costing improvement of remanufacturing crankshaft by integrating mahalanobis-taguchi system and activity based costing", IOP Conference Series: Materials Science and Engineering, 342, 1-10, 2018.

[5] Zaini S.N.A.M. and Abu M.Y. "A Review on time-driven activity based costing system in various sectors", Journal of Modern Manufacturing Systems and Technology, 2, 15-22, 2019.

[6] Erhun F., Mistry B., Platchek T., Milstein A., Narayanan V.G. and Kaplan R.S. "Time-driven activity-based costing of multivessel coronary artery bypass grafting across national boundaries to identify improvement opportunities: study protocol”, BMJ Open, 5(8), e008765, 2015.

[7] Ridderstrale, M. "Comparison between individually and group-based insulin pump initiation by time-driven activity-based costing", J Diabetes Sci Technol, 11(4), 759-765, 2017.

[8] Zamrud N.F., Abu M.Y., Nik Mohd Kamil N.N. and Safeiee F.L.M. "The Impact of Capacity Cost Rate and Time Equation of Time-Driven Activity-Based Costing (TDABC) on Electric Component", Proceedings of the International Manufacturing Engineering Conference \& The Asia Pacific Conference on Manufacturing Systems, 81-87, 2020.

[9] Nik Mohd Kamil N.N., Abu M.Y., Zamrud N.F. and Safeiee F.L.M. "Analysis of Magnetic Component Manufacturing Cost Through the Application of Time-Driven Activity-Based Costing", Proceedings of the International Manufacturing Engineering Conference \& The Asia Pacific Conference on Manufacturing Systems, 74-80, 2020.

[10] Mohd Safeiee F.L., Abu M.Y., Nik Mohd Kamil N.N. and Zamrud N.F. "The Application of Time-Driven Activity Based Costing System on Inductors in Electrics and Electronics Industry", Proceedings of the International Manufacturing Engineering Conference \& The Asia Pacific Conference on Manufacturing Systems, 88-95, 2020.

[11] Tsai W.H., Chang J.C., Hsieh C.L., Tsaur and Wang C.W. "Sustainability concept in decisionmaking: carbon tax consideration for joint product mix decision", Sustainability, 8(12), 1-22, 2016.

[12] Zhuang Z.Y. and Chang S.C. "Deciding product mix based on time-driven activity-based costing by mixed integer programming", Journal of Intelligent Manufacturing, 28(4), 959-974, 2017.

[13] Keel G., Savage C., Rafiq M. and Mazzocato P. "Time-driven activity-based costing in health care: A systematic review of the literature", Health Policy, 121(7), 755-763, 2017.

[14] Wouters M. and Stecher J. "Development of real-time product cost measurement: A case study in a medium-sized manufacturing company", International Journal of Production Economics, 183, 235-244, 2017.

[15] Sarokolaei M.A., Saviz M., Moradloo M.F. and Dahaj N.S. "Time driven activity based costing by using fuzzy logics", Procedia - Social and Behavioral Sciences, 75, 338-345, 2013.

[16] Anzai Y., Heilbrun M.E., Haas D., Boi L., Moshre K., Minoshima S. and Lee V.S. "Dissecting costs of CT study: application of TDABC (time-driven activity-based costing) in a tertiary academic center", Acad Radiol, 24(2), 200-208, 2017.

[17] Yu Y.R., Abbas P.I., Smith C.M., Carberry K.E., Ren H., Patel B. and Lopez M.E. "Time-driven activity-based costing: A dynamic value assessment model in pediatric appendicitis", J Pediatr Surg, 52(6), 1045-1049, 2017.

[18] Yun B.J., Prabhakar A.M., Warsh J., Kaplan R., Brennan J., Dempsey K.E. and Raja A.S. “Timedriven activity-based costing in emergency medicine", Ann Emerg Med, 67(6), 765-772, 2016.

[19] Kont KR. "How to optimize the cost and time of the acquisitions process?", Collection Building, 34(2), 41-50, 2015a. 